\title{
Near-normalisation of diurnal glucose concentrations by continuous administration of glucagon-like peptide-1 (GLP-1) in subjects with NIDDM
}

\author{
J . R achman, B . A . B arrow, J . C . L evy, R . C. Turner \\ D iabetes R esearch L aboratories, N uffield D epartment of Clinical M edicine, U niversity of Oxford, U K
}

Summary The gut hormone, glucagon-like peptide-1 (GLP-1) is a potent insulin secretogogue with potential as a therapy for non-insulin-dependent diabetes mellitus (NID D M ). G L P-1 has been shown to reduce glucose concentrations, both basally, and, independently, in response to a single meal. For it to be an effective treatment, it would need to be administered as a long-acting therapy, but this might not be feasible due to the profound delay in gastric emptying induced by GLP-1. In order to assess the feasibility and efficacy of continuous administration of G LP-1 in NIDDM, we determined the effects of continuous intravenous infusion of GLP-1 (7-36) amide, from 22.00-17.00 hours, on glucose and insulin concentrations overnight and in response to three standard meals, in eight subjects with NIDDM. These were compared with responses to $0.9 \% \mathrm{NaCl}$ infusion and responses in six non-diabetic control subjects who were not receiving GLP-1. E ffects on beta-cell function were assessed in the basal state using homeostasis model assessment (HOMA) and in the postprandial state by dividing incremental insulin responses to breakfast by incremental glucose responses. To assess possible clinical benefit from priming of beta cells by GLP-1 given overnight only, a third study assessed the effect of GLP-1 given from 22.00-07.30 hours on subsequent glucose responses the next day. Continuous G LP-1 infusion markedly reduced overnight glucose concentrations (mean from 24.00-08.00 hours) from median (range) 7.8 $(6.1-13.8)$ to $5.1(4.0-9.2) \mathrm{mmol} / \mathrm{l}(\mathrm{p}<0.02)$, not significantly different from control subjects, 5.6 (5.05.8) $\mathrm{mmol} / \mathrm{l}$. D aytime glucose concentrations (mean from $08.00-17.00$ hours) were reduced from 11.0 (9.3-16.4) to $7.6(4.9-11.5) \mathrm{mmol} / \mathrm{l}(\mathrm{p}<0.02)$, not significantly different from control subjects, 6.7 (6.57.0) $\mathrm{mmol} / \mathrm{l}$. GLP-1 improved beta-cell function in the basal state from 62 (13-102) to $116(46-180) \% \beta$ $(p<0.02)$ and following breakfast from 57 (19-185) to $113(31-494) \mathrm{pmol} / \mathrm{mmol}(\mathrm{p}<0.02)$. GLP-1 only given overnight did not improve the glucose responses to meals the next day. In conclusion, continuous infusion of G L P-1 markedly reduced diurnal glucose concentrations, suggesting that continuous G L P1 administration may be a useful therapy in NIDDM . [D iabetologia (1997) 40: 205-211]

Keywords Glucagon-like peptide-1, non-insulin-dependent diabetes mellitus, glucose concentrations, beta-cell function.
R eceived: 3 July 1996 and in final revised form: 230 ctober 1996

Corresponding author: Dr. J.Rachman, Diabetes R esearch $L$ aboratories, R adcliffe Infirmary, Oxford OX $26 \mathrm{HE}, \mathrm{UK}$ A bbreviations: NID D M , N on-insulin-dependent diabetes mellitus; GLP-1, glucagon-like peptide-1; HOMA, homeostasis model assessment.
Non-insulin-dependent diabetes mellitus (NIDDM) is characterised by an increase in basal glucose concentrations, upon which are superimposed exaggerated postprandial glucose excursions, induced by a combination of beta-cell dysfunction and impaired insulin sensitivity [1]. Sulphonylurea therapy improves beta-cell function approximately twofold [2], but the marked insulin secretory defect persists in most patients, so that the enhancement is usually insufficient to maintain near-normal glucose concentrations, 
either basally [3] or after meals [4]. O ther agents which can improve beta-cell function are required.

The beta-cell insulin response to a given increase in plasma glucose is greater when the glucose has been given orally rather than intravenously [5]. This is due in part to secretion of gut hormones, termed incretins, which potentiate glucose-induced insulin secretion [6]. The peptides which appear to make the greatest contribution are gastric inhibitory peptide and specific truncated forms of glucagon-like peptide-1 (G L P-1) [7, 8]. The latter are derived from the pre-proglucagon gene by tissue-specific post-translational processing [9] and are secreted from the $L$-cells of the distal ileum and colon. The incretin forms of this peptide are GLP-1 (7-37) and GLP-1 (736) amide, the latter being the naturally occurring form in humans [10]. For ease of expression, we will refer to these active truncated peptides as G L P-1.

G L P-1 is a potent stimulator of insulin secretion in the perfused pancreas [11-13]. A 4-h intravenous infusion of GLP-1 has been shown to reduce fasting glucose concentrations to near-normal in NIDDM subjects with poor glycaemic control on maximal tablet therapy [14] and a 10-h, overnight infusion in NIDDM subjects, maintained near-normal glucose concentrations overnight [15]. Continuous intravenous infusion of GLP-1 in NIDDM subjects improved the impaired basal beta-cell function and the impaired first- and second-phase insulin responses to intravenous glucose into the normal range [15]. This global improvement in beta-cell function suggested that, in addition to reducing overnight/fasting glucose concentrations, continuous stimulation by GLP-1 may also reduce the exaggerated postprandial glucose excursions of NIDD M. A dministration of GLP1 before a single meal by a brief intravenous infusion [16] or by subcutaneous injections [17], has been shown to decrease postprandial glucose excursions, but to have no effect on subsequent basal glucose concentrations. Thus, previous studies have shown efficacy of G LP-1 in the basal state and, independently, during a single meal, but in order for it to be an effective treatment for reduction of both overnight and daytime glucose concentrations, it would need to be administered as a long-acting therapy, in the basal state and through meals. Giving G L P-1 through several consecutive meals, however, may not be possible as G L P-1 profoundly delays gastric emptying [18, 19].

This study was performed in order to determine the feasibility and efficacy of continuous administration of GLP-1 in NIDDM , by assessing the effect of a 19-h, continuous intravenous infusion of G LP-1 on glucose concentrations overnight and in response to three standard meals in NID D M subjects.

In vitro studies have shown that prior exposure of beta cells to GLP-1 has a priming effect on their subsequent insulin response to glucose $[20,21]$. Since this suggested that overnight administration of
Table 1. Clinical characteristics of subjects studied

\begin{tabular}{lcc}
\hline & $\begin{array}{l}\text { Diabetic } \\
\text { patients } \\
(\mathrm{n}=7)\end{array}$ & $\begin{array}{l}\text { Control } \\
\text { subjects } \\
(\mathrm{n}=6)\end{array}$ \\
\hline A ge (years) & $60.1 \pm 12.6$ & $59.5 \pm 10.3$ \\
Sex (male/female) & $5 / 2$ & $2 / 4$ \\
Body mass index $\left(\mathrm{kg} \cdot \mathrm{m}^{-2}\right)$ & $29.4 \pm 4.9$ & $29.2 \pm 4.4$ \\
Fasting plasma glucose $(\mathrm{mmol} / \mathrm{l})$ & $9.5 \pm 2.9$ & $5.5 \pm 0.5$ \\
\hline
\end{tabular}

Values are mean \pm SD

GLP-1 might sufficiently prime the beta cells and that the clinical benefit would persist during the next day, we also evaluated whether an overnight GLP-1 infusion, that was stopped before breakfast, would maintain improved glucose control during the day. Thus, if continuous administration of G LP-1 was not feasible because of profound delay in gastric emptying through meals, overnight therapy - potentially with an intermediate acting injection of G L P-1-might be a feasible option, if continued benefit the next day could also be demonstrated.

\section{Subjects and methods}

Subjects. E ight patients with NIDDM, who were maintaining their usual body weight, were studied, together with six non-diabetic control subjects of similar age and level of obesity. Seven of the eight diabetic subjects completed the part of the study where GLP-1 was given continuously for $19 \mathrm{~h}$ and were included in the main analyses. Their characteristics, together with those of the control subjects, are shown in Table 1. The diabetic subjects had all met World $\mathrm{H}$ ealth O rganisation criteria for NIDDM at diagnosis and had been treated with either diet alone $(n=4)$, or with additional sulphonylureas $(n=3)$. The oral hypoglycaemic agents were discontinued at least 3 weeks before entry into the study. The non-diabetic control subjects all had normal fasting glucose values and had normal glucose responses to a standard meal-tolerance test. The study was approved by the Central Oxford Research and Ethics Committee and all subjects gave written informed consent.

Protocol. The diabetic subjects were admitted to an investigation unit at 21.00 hours on three occasions, having finished their last meal by 19.00 hours. Two intravenous cannulae were inserted under local anaesthetic. Blood samples were taken from the distal forearm, which was heated with a thermoregulated blanket to arterialize venous blood. A t 22.00 hours, after having drawn preinfusion blood samples, intravenous infusions of GLP-1 (7-36) amide (Bachem, Calif., USA) or placebo $(0.9 \% \mathrm{NaCl}$, saline), both containing $0.45 \%$ human serum albumin (Bio-Products Laboratory, Elstree, Herts, UK), were commenced. Infusions were continued until 17.00 hours the following day. Saline infusion was given throughout one visit and $\mathrm{GLP}-1$, given at a rate of $1.2 \mathrm{pmol} \cdot \mathrm{kg}^{-1} \cdot \mathrm{min}^{-1}$, was infused on two visits, once throughout and once stopping at 07.30 hours, with saline infusion for the remainder of that day. The infusions were given in randomised order. On all three nights, blood was drawn hourly for laboratory plasma glucose measurement and 2 hourly for insulin. The following day, subjects received three standard meals. B reakfast $(397 \mathrm{kcal}$, $57.1 \mathrm{~g}$ carbohydrate) was given at 08.00 hours; lunch 
( $609 \mathrm{kcal}, 70.4 \mathrm{~g}$ carbohydrate) at 12.00 hours and afternoon snack (199 kcal, $26.4 \mathrm{~g}$ carbohydrate) at 15.00 hours. Blood samples were taken intermittently throughout the day. Nondiabetic control subjects attended on one occasion and underwent the identical overnight and daytime protocol, without GLP-1.

Biochemical assays. Blood samples were drawn into plastic tubes containing heparin and were immediately placed on ice. The samples were centrifuged at $4^{\circ} \mathrm{C}$. Plasma glucose concentrations were measured that day and plasma samples for insulin stored at $-20^{\circ} \mathrm{C}$. Plasma glucose was determined by a hexokinase method on a Cobas M IRA discrete analyser (R oche D iagnostica, W elwyn G arden City, H erts, U K ). Plasma immunoreactive insulin was determined by double antibody radioimmunoassay [22]. Inter-assay coefficient of variation (C.V.) was $3.3 \%$ at $300 \mathrm{pmol} / \mathrm{l}$.

D ata analysis. G lucose control overnight was assessed in each individual by time-averaged mean of values from 24.00 to 08.00 hours, and during the day by time-averaged mean of values from 08.00 to 17.00 hours. Incremental postprandial glucose concentrations were determined in each individual by the time-averaged mean of values from 08.00 to 17.00 hours, with subtraction of the glucose concentration at 08.00 hours. Beta-cell function and insulin sensitivity were assessed at 08.00 hours by the relationship between fasting glucose and insulin concentrations, analysed by homeostasis model assessment (HOM A ) [23]. This utilises a computer model based on the known interactions of glucose and insulin in different organs including the pancreas, liver and peripheral tissues. For each individual, the model determines the beta-cell function $(\% \beta)$ and insulin sensitivity (\%S) that uniquely predict the measured fasting glucose and insulin concentrations. $\% \beta$ and $\% \mathrm{~S}$ are expressed relative to values in a lean, non-diabetic reference population aged 18-25 years, who were assigned an arbitrary mean value of $100 \%$. B eta-cell function was assessed in the postprandial state in each individual by dividing the time-averaged mean incremental insulin concentration for the period $08.00-11.00$ hours by the time-averaged mean incremental glucose concentration for the same period.

Statistical analysis. Results are expressed as median (range). The Wilcoxon signed rank test was used to compare data on the studies with saline or GLP-1 infusion in the diabetic subjects and the $\mathrm{M}$ ann $\mathrm{W}$ hitney $\mathrm{U}$-test to compare the diabetic with the control subjects.

\section{Results}

Six of the eight subjects completed all three parts of the study. Four of these subjects had no side-effects and two had mild nausea at some stage during the night when G L P-1 was given, which settled spontaneously. In the study when G LP-1 was continued throughout the day, the seventh subject experienced nausea in the night, continuing through breakfast, requiring discontinuation of the infusion. This subject was not included in the data analyses. The eighth subject had no symptoms during the study where GLP-1 was given throughout, but unexpectedly developed nausea and vomiting during the visit where G LP-1 was to be given overnight only, requiring its discontinuation.
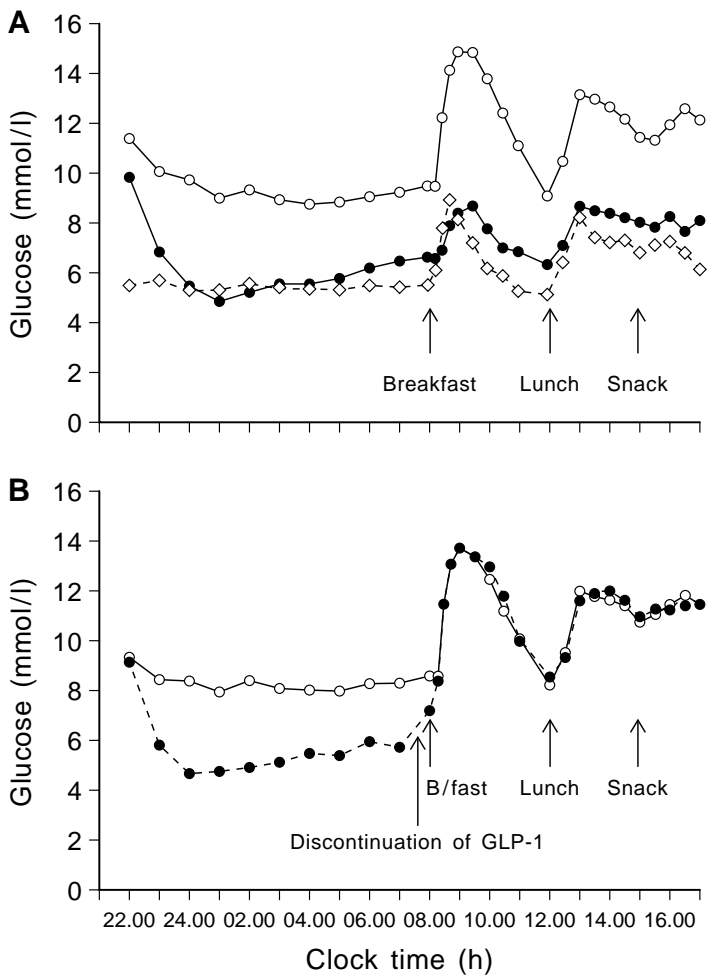

Fig. 1. (A) M ean diurnal plasma glucose concentrations in diabetic subjects in response to infusion of saline - $\mathrm{O}$ - or continuous infusion of G LP-1 —- compared with non-diabetic control subjects - - -- . (B) M ean diurnal plasma glucose concentrations in diabetic subjects in response to infusion of saline $\bigcirc$ or infusion of G L P-1 from 22.00 to 07.30 hours

$O$ vernight and daytime glucose concentrations in the control subjects and the seven diabetic subjects on the continued GLP-1 and saline infusion study days are shown in Figure $1 \mathrm{a}$. The diabetic subjects on saline had the expected hyperglycaemia due to a combination of raised basal glucose concentrations and exaggerated postprandial glucose excursions. During the GLP-1 infusion, glucose concentrations fell rapidly over the first $2 \mathrm{~h}$ and marked reduction of both overnight and daytime glucose concentrations, to near-normal levels, was maintained. M ean overnight and daytime glucose concentrations in each individual are shown in Figure 2. On the saline infusion, the diabetic subjects had overnight glucose concentrations (time-averaged mean from 24.00 to 08.00 hours in each individual) of median (range), $7.8(6.1-13.8) \mathrm{mmol} / \mathrm{l}$, higher than control subjects, $5.6(5.0-5.8) \mathrm{mmol} / /(p<0.001)$ (Fig. 2a). Continuous GLP-1 infusion reduced this to $5.1(4.0-9.2) \mathrm{mmol} / \mathrm{l}$ $(p<0.02$, compared with saline), not significantly different from control subjects. Glucose concentrations remained constant from 24.00 hours to 08.00 hours in both the diabetic subjects on the saline infusion and the control group, but during GLP-1 infusion, rose at a rate of $0.2 \mathrm{mmol} \cdot \mathrm{I}^{-1} \cdot \mathrm{hr}^{-1}$ (Fig. 1a). 

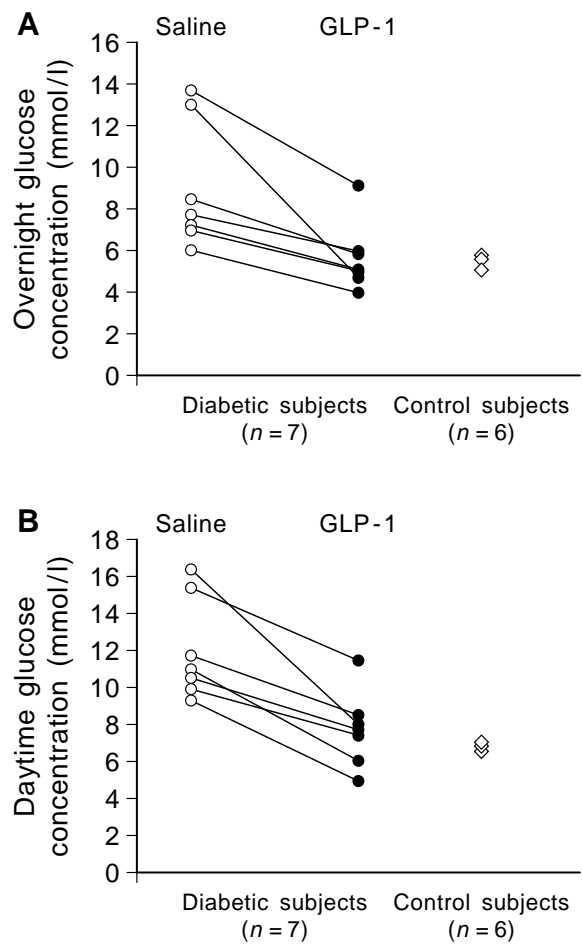

Fig. 2A , B. M easurements of (A) overnight glucose concentrations (time-averaged mean 24.00-08.00 hours) and (B ) daytime glucose concentrations (time-averaged mean 08.0017.00 hours), in individual diabetic subjects in response to infusion of saline $\bigcirc$ or continuous infusion of G LP-1 • compared with individual non-diabetic control subjects $\diamond$

Daytime glucose concentrations (time-averaged mean from 08.00 to 17.00 hours in each individual) were raised in the diabetic subjects receiving saline infusion, 11.0 (9.3-16.4) $\mathrm{mmol} / \mathrm{l}$, compared with control subjects, $6.7 \quad(6.5-7.0) \mathrm{mmol} / \mathrm{l} \quad(p<0.001)$ (Fig. 2 b). Continuous G L P-1 infusion reduced this to 7.6 (4.9-11.5) $\mathrm{mmol} / / \mathrm{l}(\mathrm{p}<0.02$, compared with saline), not significantly different from control subjects. In addition to reduction in baseline glucose concentrations, the incremental postprandial glucose concentrations were markedly reduced by GLP-1 from $2.7(1.0-3.6) \mathrm{mmol} / \mathrm{l}$ on saline infusion to $0.8(0.5-$ 1.9) $\mathrm{mmol} / \mathrm{l}(p<0.02)$, not significantly different from control subjects, $1.1(0.4-2.3) \mathrm{mmol} / \mathrm{l}$.

In the seven subjects who completed the overnight GLP-1 study, when the infusion was discontinued 30 min before breakfast, the glucose concentrations rose within the $30 \mathrm{~min}$ before breakfast and, during the day, returned to the levels recorded with saline infusion (Fig. 1b).

$O$ vernight and daytime insulin concentrations in the control subjects and the diabetic subjects on the continued GLP-1 and saline infusion studies are shown in Figure 3, with the expected daytime insulin levels lower in the diabetic subjects than the control subjects. Figure 4 shows measures of basal and postprandial beta-cell function in each individual. At

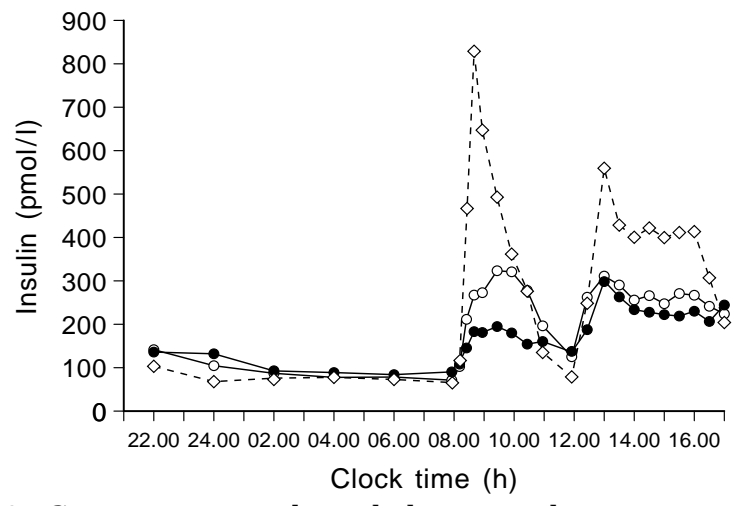

Fig. 3. G eometric mean diurnal plasma insulin concentrations in diabetic subjects in response to infusion of saline - $-\mathrm{O}-$ or continuous infusion of G LP-1 - - c compared with non-diabetic control subjects - - $\checkmark-$ -

08.00 hours, the diabetic group on the saline infusion visit had basal beta-cell function (assessed by HOM A ), of median (range), 62 (13-102) \% $\beta$, lower than in the similarly obese control subjects, 106 (93$125) \% \beta(p<0.005)$ (Fig. $4 a)$. With continuous infusion of G L P-1, basal beta-cell function in the diabetic group improved to 116 (46-180) \% $\beta$ ( $p<0.02$, compared with saline), not significantly different from control subjects. The insulin response relative to the glycaemic stimulus postprandially was assessed in each individual by the mean insulin increment divided by the mean glucose increment over the $3 \mathrm{~h}$ after breakfast. The responses in the diabetic subjects on saline infusion, 57 (19-185) $\mathrm{pmol} / \mathrm{mmol}$, were lower than those of the control subjects, 268 (105634) $\mathrm{pmol} / \mathrm{mmol}(p<0.001)$ (Fig. $4 \mathrm{~b})$. Continuous GLP-1 in the diabetic subjects improved this to 113 (31-494) $\mathrm{pmol} / \mathrm{mmol}(p<0.02$, compared with saline). A lthough this was not significantly different from control subjects $(p=0.051)$, most subjects remained at the lower end of, or below, the control range (Fig. 4 b).

Insulin sensitivity determined at 08.00 hours, by HOMA, was similar in the diabetic subjects during saline infusion and control subjects, 32 (11-71) \% S and $41(25-75) \% \mathrm{~S}$, respectively, and in the diabetic subjects, did not change significantly in response to G L P-1 infusion, 19 (15-95) \% S.

\section{Discussion}

This study showed that continuous infusion of G L P-1 markedly improved both overnight and daytime glucose concentrations in subjects with NIDDM, without delayed gastric emptying causing side-effects after several consecutive meals. This suggests that continuous administration of G LP-1, by long-acting subcutaneous formulation or other means, would be a feasible and efficacious therapy for NIDDM. 

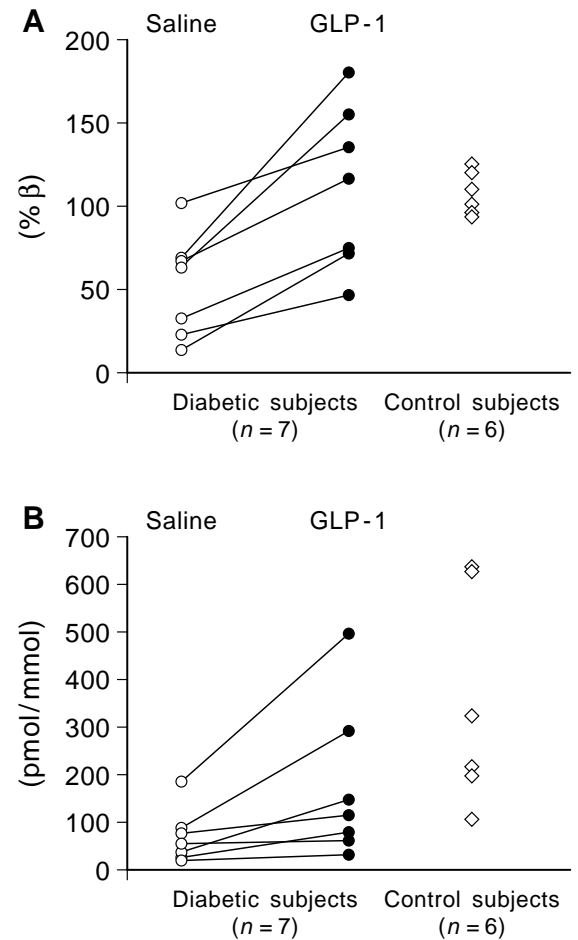

Fig. 4A , B. M easurements of (A) basal (08.00 hours) beta-cell function and (B) postprandial insulin/glucose increments, in individual diabetic subjects in response to infusion of saline $O$ or continuous infusion of G LP-1 • compared with individual non-diabetic control subjects $\diamond$

Continuous infusion of $G L P-1$ resulted in reduction of both basal glucose concentrations and postprandial glucose increments. Current therapy with sulphonylureas [4], metformin [24] or single dose daily longacting insulin [4] reduces basal glucose concentrations with little effect on the exaggerated postprandial glucose increments typical of NIDD M, and therapy with acarbose reduces postprandial glucose increments with little effect on basal glucose concentrations [25]. Thus, therapy with continuous administration of GLP-1 is the only known single therapy that substantially reduces both basal and postprandial glucose concentrations to near-normal.

The overnight plasma insulin concentrations during the GLP-1 infusion were similar to those during the saline infusion. A previous study of intravenous GLP-1 administration to subjects with NIDDM showed an initial increase in insulin concentrations with GLP-1, which returned to the original concentrations when the plasma glucose approached normal [14]. It is likely that the marked decrease in glucose concentrations over the first $2 \mathrm{~h}$ of the GLP-1 infusion in this study was similarly due to an initial increase in insulin concentrations, which was not detected since no measurements were taken until $2 \mathrm{~h}$ after commencement of the infusion, by which time the glucose concentrations were already normal. In addition, GLP-1 infusion has been shown to improve acutely insulin-independent glucose disposal [26] and reduce glucagon concentrations [14] and these effects may have also contributed to the initial decrease in glucose concentrations. L ower glucose concentrations were maintained thereafter by G L P-1-induced improvement in beta-cell function (glucose-induced insulin secretion) as shown by similar insulin concentrations during saline and GLP-1 infusions, despite significantly lower glucose concentrations with GLP-1. This improvement in basal beta-cell function was quantified by use of HOM A of the insulin concentrations at 08.00 hours relative to the glucose concentrations [23] and showed that G L P-1 improved basal beta-cell function into the normal range in most subjects.

Postprandial beta-cell function was assessed by the relationship between postprandial insulin and glucose increments. A lthough the insulin/glucose ratio improved significantly with GLP-1, in most subjects it remained at the lower end of, or below, the control range. Postprandial insulin secretion is influenced by a variety of neuroendocrine and other factors, such as rate of gastric emptying, which do not play a major role in control of basal insulin secretion. A Ithough GLP-1 markedly improved the impaired basal betacell function of subjects with NIDDM, the impaired postprandial beta-cell function was only slightly improved, suggesting that there are defects in control of postprandial insulin secretion in NIDDM for which G LP-1 does not compensate. G LP-1 normalised the postprandial glucose increments, despite not normalising postprandial insulin secretion, and its other known effects are likely to have contributed, such as delay in gastric emptying $[18,19]$, which may allow the glucose load after meals to be more efficiently handled by the impaired beta cells, and enhancement of insulin-independent glucose disposal $[26,27]$.

The study where G LP-1 was given overnight and discontinued before breakfast showed no reduction of glucose concentrations the following day, suggesting that G L P-1 induced priming of beta cells, demonstrated in in vitro studies $[20,21]$ has little clinical relevance.

In vitro [13, 21, 28] and in vivo [14] studies have suggested that the insulinotropic actions of GLP-1 are highly glucose dependent, i.e. greater at raised than normal glucose concentrations, and none of the subjects in this study experienced hypoglycaemia with G L P-1. Two of the eight subjects studied experienced significant side-effects of nausea or vomiting and two experienced mild, transient nausea with GLP-1. The dose of GLP-1 used was empirical and based on our own [15] and other groups' [14] experiences with similar doses. This is the first study to report side-effects with G LP-1 in diabetic subjects, although vomiting has been reported in non-diabetic subjects given very high doses of G L P-1 [29]. G L P-1 
has binding sites in the rat brain $[30,31]$ and its effects on gastric emptying and acid secretion could be centrally mediated [30]. The symptoms in this study occurred overnight, but may nevertheless have been due to delayed gastric emptying. It was reassuring, however, that no symptoms occurred after any of the meals, as previous studies have suggested that continuous administration of G L P-1 may not be feasible because of profound inhibition of postprandial gastric emptying [18]. Further studies will reveal whether the overnight side-effects might restrict the clinical use of G L P-1 and whether doses giving lower plasma concentrations of G LP-1 would be similarly effective with less likelihood of symptoms. A dditional studies to evaluate whether continuous administration of GLP-1 will be similarly effective in more hyperglycaemic subjects are also required.

The effects of G L P-1 on the beta cell are mediated via a specific GLP-1 receptor $[32,33]$ that activates adenylate cyclase, resulting in increased cyclic adenosine monophosphate (CA M P) levels. A ctivation of CA M P-dependent protein kinases, such as protein kinase $A$, may increase insulin release via a number of mechanisms [21, 34-36]. A potential problem with supraphysiological doses of G L P-1 is that tachyphylaxis might occur due to down-regulation of its receptors or post-receptor mechanisms. The rise in overnight fasting glucose from 24.00 to 08.00 hours on G L P-1 was greater than the rise on saline or in control subjects, suggesting that G LP-1 may have been losing efficacy overnight. A recently reported study of 1-week infusion of GLP-1 in subjects with NIDDM [37], however, showed similar efficacy on days 1 and 7 , suggesting that tachyphylaxis is unlikely to occur with continuous administration of G LP-1.

In conclusion, this study has established, in principle, that G LP-1 given continuously has the ability to reduce both overnight and daytime glucose concentrations in subjects with NIDDM. Continuous infusion of G LP-1 is not a feasible therapy, but continuous administration of GLP-1, given by another route such as a long-acting subcutaneous formulation, may have therapeutic relevance in NIDDM, particularly as GLP-1 gives little risk of hypoglycaemia due to the glucose dependency of its action.

Acknowledgements. We are grateful to MS. P.Sutton, M S. N. L awrence and M r. R. M air for performing the biochemical assays. The study was supported by an academic grant from Eli Lilly. J.R. is a recipient of a Baron Hartley Scholarship from the $U$ niversity of Cape Town and a U nited Kingdom $O$ verseas $R$ esearch Studentship.

\section{References}

1. Defronzo R A (1988) The triumvirate: $\beta$-cell, muscle, liver. A collusion responsible for NIDD M . D iabetes 37: 667-687 2. H osker J P, B urnett M A , D avies E G, H arris E A, Turner R C (1985) Sulphonylurea therapy doubles $\beta$-cell responses to glucose in type 2 diabetic patients. D iabetologia 28: 809814

3. UK Prospective Diabetes Study 16 (1995) Overview of 6 years' therapy of type II diabetes: a progressive disease. D iabetes 44: 1249-1258

4. Holman R R, Turner R C (1978) B asal normoglycemia attained with chlorpropamide in mild diabetes. Metabolism 27: $539-547$

5. N auck M , Stöckmann F, E bert R , Creutzfeldt W (1986) R educed incretin effect in type 2 (non-insulin-dependent) diabetes. D iabetologia 29: 46-52

6. Creutzfeld W (1979) The incretin concept today. Diabetologia 16: 75-85

7. Kreymann B, G hatei MA, Williams G, Bloom SR (1987) Glucagon-like peptide-1: a physiological incretin in man. L ancet 1300-1303

8. Nauck M A ; B artels E, Ørskov C, E bert R, Creutzfeld W (1993) A dditive insulinotropic effects of exogenous synthetic human gastric inhibitory polypeptide and glucagonlike peptide-1-(7-36) amide infused at near-physiological insulinotropic hormone and glucose concentrations. J Clin E ndocrinol M etab 76: 912-917

9. Mojsov S, H einrich $G$, Wilson IB, R avazzola M, Orci L, $\mathrm{H}$ abener JF (1986) Preproglucagon gene expression in pancreas and intestine diversifies at the level of post-translational processing. J Biol Chem 261: 11880-11889

10. Ørskov C, Bersani M, Johnsen A H, Højrup P, Holst JJ (1989) Complete sequences of glucagon-like peptide-1 from human and pig small intestine. J Biol Chem 264: 12826- 12829

11. Holst J J, Ø rskov C, Vagn N ielsen O, Schwartz TW (1987) Truncated glucagon-like peptide 1 , and insulin-releasing hormone from the distal gut. FE BS L ett 211: 169-174

12. M ojsov S, Weir G C, H abener J F (1987) Insulinotropin: glucagon-like peptide 1 (7-37) coencoded in the glucagon gene is a potent stimulator of insulin release in the perfused rat pancreas. J Clin Invest 79: 616-619

13. Weir G C, M ojsov S, H endrick G K, H abener J F (1989) G lucagonlike peptide 1 (7-37) actions on endocrine pancreas. D iabetes 38: 338-342

14. Nauck MA, Kleine $N, \emptyset$ rskov C, Holst J, Willms B, Creutzfeldt W (1993) Normalization of fasting hyperglycaemia by exogenous glucagon-like peptide 1 ( 7-36 amide) in type 2 (non-insulin-dependent) diabetic patients. Diabetologia 36: 741-744

15. R achman J, G ribble FM, B arrow B A, L evy J C, Buchanan $K D$, Turner R C (1996) N ormalization of insulin responses to glucose by overnight infusion of glucagon-like peptide1 (7-36) amide in patients with NIDDM. Diabetes 45: $1524-1530$

16. G utniak M, Ø rskov C, H olst JJ , A hrén B , E fendic S (1992) A ntidiabetogenic effect of glucagon-like peptide-1 (736) amide in normal subjects and patients with diabetes mellitus. N E ngl J Med 326: 1316-1322

17. G utniak M K, Linde B, H olst J J, E fendic S (1994) Subcutaneous injection of the incretin hormone glucagon-like peptide 1 abolishes postprandial glycemia in NIDD M. Diabetes Care 17: 1039-1044

18. Willms B, Werner J, Holst JJ, Ørskov C, Creutzfeldt W, Nauck MA (1996) Gastric emptying, glucose responses, and insulin secretion after a liquid test meal: effects of exogenous glucagon-like peptide-1 (G L P-1)-(7-36) amide in type 2 (noninsulin-dependent) diabetic patients. J Clin E ndocrinol M etab 81: 327-332

19. Wettergren A, Schjoldager B, Mortensen PE, M yhre J, Christiansen J, H olst JJ (1990) Truncated G L P-1 (proglucagon 78-107-amide) from distal gut: role in regulation of 
gastric and pancreatic functions. Digestion 46 [Suppl 1]: 335 (A bstract)

20. Fehmann H-C, G öke R, G öke B, B ächle R, Wagner B, A rnold $R$ (1991) Priming effect of glucagon-like peptide-1 (736) amide, glucose-dependent insulinotropic polypeptide and cholecystokinin-8 at the isolated perfused rat pancreas. Biochem Biophys A cta 1091: 356-363

21. H olz G G, K ühtreiber W M , H abener J F (1993) Pancreatic beta-cells are rendered glucose-competent by the insulinotropic hormone glucagon-like peptide-1 (7-37). Nature 361: 362-365

22. U K Prospective Diabetes Study (U K PD S) XI (1994) Biochemical risk factors in type 2 diabetic patients at diagnosis compared with age-matched normal subjects. D iabet M ed 11: 534-554

23. Matthews DR, Hosker JP, Rudenski A S, Naylor BA, Treacher D F, Turner R C (1985) H omeostasis model assessment: insulin resistance and $\beta$-cell function from fasting plasma glucose and insulin concentrations in man. Diabetologia 28: 412-419

24. Jackson R A , H awa M I, Jaspan J B et al. (1987) M echanism of metformin action in non-insulin-dependent diabetes. $\mathrm{Di}$ abetes 36: 632-640

25. Chiasson J -L, J osse R G, H unt JA et al. (1994) The efficacy of acarbose in the treatment of patients with non-insulindependent diabetes mellitus. A nn Intern M ed 121: 928-935

26. D'A lessio DA , K ahn SE, L eusner CR, E nsinck J W (1994) G lucagon-like peptide 1 enhances glucose tolerance both by stimulation of insulin release and by increasing insulinindependent glucose disposal. J Clin Invest 93: 2263-2266

27. D 'A lessio DA , Prigeon R L, E nsinck JW (1995) E nteral enhancement of glucose disposition by both insulin-dependent and insulin-independent processes. A physiological role of glucagon-like peptide 1. Diabetes 44: 1433-1437

28. Komatsu R, M atsuyama T, Namba M et al. (1989) Glucagonostatic and insulinotropic action of glucagonlike peptide 1-(7-36)-amide. Diabetes 38: 902-905
29. R itzel R, Ø rskov C, H olst JJ, Nauck M A (1995) Pharmacokinetic, insulinotropic, and glucagonostatic properties of GLP-1 (7-36 amide) after subcutaneous injection in healthy volunteers. D ose-response relationships. D iabetologia 38: $720-725$

30. Ørskov C, Wettergren A, Poulsen SS, H olst JJ (1995) Is the effect of glucagon-like peptide-1 on gastric emptying centrally mediated? D iabetologia 38 [Suppl 1]: A 39 (A bstract)

31. K anse SM, K reymann B, G hatei M A, Bloom SR (1988) Identification and characterization of glucagon-like peptide-1 7-36 amide-binding sites in the rat brain and lung. FE B S L ett 241: 209-212

32. Thorens $B$, Porret $A, B$ ühler $L$, D eng S-P, Morel $P$, Widmann $C$ (1993) Cloning and functional expression of the human islet GL P-1 receptor. D emonstration that exendin4 is an agonist and exendin-(9-39) an antagonist of the receptor. D iabetes 42: 1678-1682

33. Dillon J S, Tanizawa Y, Wheeler M B et al. (1993) Cloning and functional expression of the human glucagon-like peptide-1 (G L P-1) receptor. Endocrinology 133: 1907-1910

34. Yada T, I toh K, N akata M (1993) G lucagon-like peptide-1(7-36) amide and a rise in cyclic adenosine 3', 5'-monophosphate increase cytosolic free $\mathrm{Ca}^{2+}$ in rat pancreatic $\beta$ cells by enhancing $\mathrm{Ca}^{2+}$ channel activity. Endocrinology 133: 1685-1692

35. H olz G G, Leech CA, Habener JF (1995) A ctivation of a CA M P-regulated $\mathrm{Ca}^{2+}$-signaling pathway in pancreatic $\beta$ cells by the insulinotropic hormone glucagon-like peptide1. J Biol Chem 270: 17749-17757

36. Ä mmälä C, A shcroft F M , R orsman P (1993) Calcium-independent potentiation of insulin release by cyclic A MP in single $\beta$-cells. N ature 363: 356-358

37. L arsen J, Jallad N, D amsbo P (1989) O ne-week continuous infusion of G L P-1 (7-37) improves the glycaemic control in NID D M . Diabetes 45 [Suppl 2]: 232A (A bstract) 